\title{
Survey, diagnosis and identification of resistant source of leaf curl virus infecting papaya (Carica papaya L.) in India
}

\author{
Shyam Singh' ${ }^{1}$, and Awasthi LP2* \\ ${ }^{1}$ S.K. College of Agriculture and Research Station (IGKV), Kawardha (Kabirdham)-491995, Chhattisgarh, India \\ ${ }^{2}$ Amity Center for Research and Innovation (Amity University Uttar Pradesh), Varanasi-221007, U.P, India
}

\begin{abstract}
A survey conducted, at the orchards of papaya at different locations in India, revealed that the incidence of leaf curl disease ranged from $13.00-32.00$ per cent and 12.00-28.00 per cent during 2006-07 and 2007-08 respectively. Maximum incidence of leaf curl (27.50\%), during 2006-07, was recorded in District Etawah. Whereas, maximum leaf curl disease incidence (23.50\%), during 2007-08, was recorded in Lucknow district. Symptoms of papaya leaf curl disease appeared in the form of severe distortion of leaves associated with curling and rolling of leaves, leathery leaf, vein zigzag and reduction in the size of petioles, internodes, and main shoot. As for as varietal response was concerned, maximum leaf curl incidence ( 80.00 and $86.67 \%$ ) was observed in cultivar Co-4 followed by MF-1 ( 80.00 and 83.33\%). While minimum leaf curl incidence (23.33 and 20.00 percent) was observed on Harichaap cultivar during 2006-07 and 2007-08, respectively. Variety Harichaap was found resistant against leaf curl disease during both the years. Six cultivars (varieties) viz., CO-2, CO-3, CO-6, Coorghoneydew, Pusa Delicious and Pusa Dwarf were rated as moderately resistant.
\end{abstract}

\section{Introduction}

Papaya (Carica papaya L.) is a popular and economically important fruit tree of tropical and subtropical countries in the World. Papaya provides economically important edible fruits and is considered to be one of the most important sources of vitamins A and C. In addition, papaya contains enzyme papain and chymopapain, both of which are widely used in the food industry and for medical purposes. It is consumed world-wide as fresh ripen fruit as well as vegetable besides, in the preparation of various value added products. This crop is badly affected by many biotic factors such as fungi, bacteria, viruses and nematodes. Among them viruses are the limiting factor for the cultivation of papaya in India, especially northern India. Large number of viruses have been reported time to time on papaya which belong to cucumo, gemini-, ilar-, poty-, rhabdo-, tobra-and tospo- virus group [1]. In India, leaf curl virus is the second important virus infecting papaya, after papaya ring spot virus. It was first reported from Puerto Rico as Curly leaf $[2,3]$. In India, it was first reported from Coimbatore [4]. Subsequently this disease was reported from different states in India [5-7]. Leaf curl disease is characterized by severe curling, crinkling and distortion of leaves along with reduction of petiole and internodes and also the main shoot. Papaya leaf curl virus, of geminivirus group, is transmitted by whitefly (Bemisia tabaci) under natural conditions. Singh, et al. reported that whiteflies can transmit leaf curl virus to an extent of $70 \%$ when they feed on Ninnia elengans plants infected with tobacco leaf curl virus [8]. Whiteflies require a latent period to become viruliferous. Verma [9] recorded $60 \%$ incidence of this disease in Northern India. There is no much information available on the incidence of papaya leaf curl disease on different varieties of papaya and also about the characteristics of this virus. Therefore, keeping in view above fact, the present research work was carried out on survey, diagnosis and identification of resistance source of leaf curl virus infecting papaya (Carica papaya L.)" in India.

\section{Materials and methods}

Survey for the incidence and symptomatology of papaya leaf curl virus

An experiment was conducted on the survey, diagnosis and characterization of leaf curl virus infecting papaya (Carica papaya L.)" at the N. D. University of Agriculture and Technology, Kumarganj, Faizabad (Uttar Pradesh), India. Field survey for the incidence of viral diseases in papaya was carried out at four locations of Etawah, Faizabad, Lucknow and Varanasi districts of Uttar Pradesh. Each locality was surveyed on one year old papaya orchards only for the incidence of papaya leaf curl virus. At each location, 200 plants of papaya were tagged for recording of data on incidence and symptomatology. Observations for the incidence of leaf curl disease and type of symptoms were recorded in the field and the percent incidence of the disease was calculated by the following formula:

Percent disease incidence $=\frac{\text { Number of infected plants in field }}{\text { Total number of plants (infected }+ \text { healthy) in field }} \times 100$

Response of different papaya varieties against artificial inoculation of papaya leaf curl virus through white flies under glass house

Seeds of 16 papaya cultivars were procured from N. D. University of Agriculture and Technology, Kumarganj, Faizabad, Uttar Pradesh,

Correspondence to: Awasthi LP, Amity Center for Research and Innovation (Amity University Uttar Pradesh), Varanasi-221007, U.P, India, Tel: 919415718904 ; E-mail: lpawasthi14@gmail.com

Key words: artificial inoculation, diagnosis, papaya, papaya leaf curl virus, source of resistance

Received: February 28, 2017; Accepted: March 14, 2017; Published: March 17, 2017 
Indian Institute of Horticulture Research, Bangalore and Tamil Nadu Agriculture University, Coimbatore. Healthy seedlings of each variety were transplanted in the pots filled with sterilized soil. Ten pots, planted with one seedling in each, were kept as replications. The experiment was laid out under CRD with three replications. Pots were maintained in an insect free net house under natural conditions. Varietal Details are given below:

\section{Varieties}

1. $\mathrm{CO}-1$

2. $\mathrm{CO}-5$

3. Coorg honeydew

4. Pusa Dwarf

5. $\mathrm{CO}-2$

6. $\mathrm{CO}-6$

7. Wasington

8. Pusa Majesty

9. $\mathrm{CO}-3$

10. $\mathrm{CO}-7$

11. Pusa delicious

12. Hari Chaap

13. $\mathrm{CO}-4$

14. MF-1

\section{Pusa Nanha Pusa Gaint}

The whiteflies (Bemisia tabaci Gen.), cultured on cotton plants in a separate net house were collected with the help of an aspirator and 1000 whiteflies were released on virus infected leaves under specially fabricated glass tubes for acquisition of the virus. These whiteflies were then allowed to feed on test plants (papaya seedlings) under controlled conditions for overnight. Ten whiteflies were used per test plant. After the inoculation feeding, next day seedlings were sprayed with Acephate @ $0.01 \%$ to kill the whiteflies. Observations were taken daily for the appearance of symptoms and data were recorded. Incidence of papaya leaf curl disease was recorded following 1, 2 and 3 months of transplanting. The types of symptoms appeared on the seedlings of different cultivars/varieties were also observed. Disease rating was done by using standard scale [10] as mentioned below (Table 1):

\section{Results and Discussion}

Survey for disease incidence and symptomatology of papaya leaf curl virus

Results presented in Table 2 clearly indicated that leaf curl disease incidence ranged from 13.00-32.00 per cent and 12.00-28.00 per cent during 2006-07 and 2007-08 at different locations of the Uttar Pradesh, India. Maximum disease incidence $(27.50 \%)$ was recorded in District Etawah during 2006-07 whereas; during 2007-08 maximum leaf curl disease incidence $(23.50 \%)$ was recorded in Lucknow district. Average disease incidence, in one year old orchards was found maximum (24.88\%) at Etawah district followed by (24.00 per cent) Lucknow, (17.88 per cent) Faizabad and (17.25 per cent) Varanasi district. However, in one year papaya old orchards, maximum disease incidence recorded
Table 1. Disease rating done by using standard scale (Anonymous, 2004).

\begin{tabular}{|c|c|c|}
\hline Grade & $\begin{array}{c}\text { Description } \\
\text { (average disease incidence in per cent) }\end{array}$ & Reaction/ category \\
\hline I & 0.00 & Immune \\
\hline II & $0.1-25.0$ & Resistant \\
\hline III & $25.1-50.0$ & Moderately resistant \\
\hline IV & $50.1-75.0$ & Susceptible \\
\hline V & $75.1-100.00$ & Highly susceptible \\
\hline
\end{tabular}

Table 2. Survey of papaya fields in different districts for the incidence of papaya leaf curl virus disease.

\begin{tabular}{|c|c|c|c|c|}
\hline \multirow{2}{*}{ S. No. } & \multirow{2}{*}{ Districts/village } & \multicolumn{3}{|c|}{ Papaya leaf curl virus disease incidence $(\%)$} \\
\hline & & 2006-07 & 2007-08 & Mean \\
\hline & \multicolumn{4}{|c|}{ Etawah } \\
\hline & Nagala Chhiddi & 32.00 & 28.00 & 30.00 \\
\hline & Birari & 24.00 & 19.00 & 21.50 \\
\hline & Jasvantnagar & 26.00 & 16.00 & 21.00 \\
\hline & Bharathana & 28.00 & 26.00 & 27.00 \\
\hline & Mean & 27.50 & 22.25 & 24.88 \\
\hline & \multicolumn{4}{|c|}{ Faizabad } \\
\hline & Ayodhyaya & 22.00 & 15.00 & 18.50 \\
\hline & Beekapur & 20.00 & 18.00 & 19.00 \\
\hline & Kumarganj & 19.00 & 20.00 & 19.50 \\
\hline & Sohawal & 16.00 & 13.00 & 14.50 \\
\hline & Mean & 19.25 & 16.50 & 17.88 \\
\hline & \multicolumn{4}{|c|}{ Lucknow } \\
\hline & Gosaiganj & 24.00 & 28.00 & 26.00 \\
\hline & Neelmathah & 26.00 & 25.00 & 25.50 \\
\hline & Rahamankhera & 22.00 & 24.00 & 23.00 \\
\hline & Thakurganj & 26.00 & 17.00 & 21.50 \\
\hline & Mean & 24.50 & 23.50 & 24.00 \\
\hline \multicolumn{5}{|c|}{ Varanasi } \\
\hline & Chirrai & 13.00 & 16.00 & 14.50 \\
\hline & Ruhaniya & 20.00 & 21.00 & 20.50 \\
\hline & Shivpur & 23.00 & 18.00 & 20.50 \\
\hline & Sirkaraiya & 15.00 & 12.00 & 13.50 \\
\hline & Mean & 17.75 & 16.75 & 17.25 \\
\hline \multicolumn{2}{|c|}{ Over all mean } & 22.25 & 19.75 & \\
\hline
\end{tabular}

was 22.5 per cent during 2006-07 and minimum 19.75 per cent during 2007-2008. Verma [9] reported 60.00 per cent leaf curl disease incidence in nursery and field plantations of papaya in Samastipur and Musafferpur districts of north Bihar and they reported that nurseries were apparently free from PRSV but mild to severe symptoms could be seen in one and two years old plantations. Papaya leaf curl disease was reported from different states of India $[4,5,9,11]$. Verma reported 60.00 per cent incidence of this disease in northern India [12].

Symptoms of papaya leaf curl disease were observed in the form of severe curling, crinkling and distortion of leaves along with reduction of petioles, internodes, and main shoot. The leaves were reduced in size and showed vein clearing. Leaf margins were rolled downwards and inwards forming the shape like inverted cups. In some cases, leaf margins rolled upwards. The leaves of infected plants turned darkgreen and become leathery and brittle. The interveinal areas of affected leaves were much raised on upper surface due to uneven growth and twisting of veins. The petioles were twisted in a zigzag manner and bend towards the main trunk. Affected plants failed to flower and in case of occasional flowering, they bear a few small and abnormal fruits. In advanced stage of disease, defoliation takes place and growth of the plants was arrested (Figure 1). It has been reported that symptoms of leaf curl disease were exhibited in the form of severe curling, crinkling, 


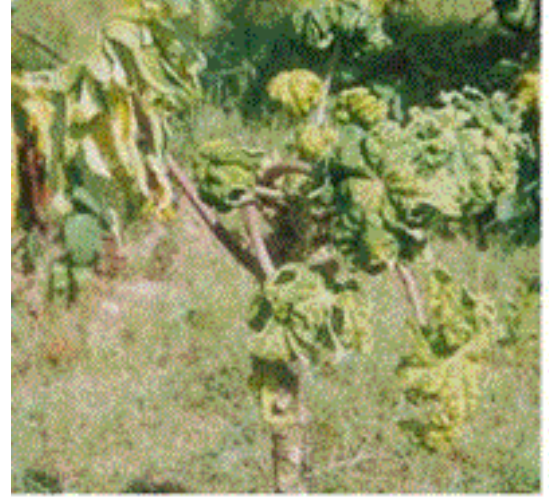

Severe curling distortion ofleaves and reduction of petioles, intamodes

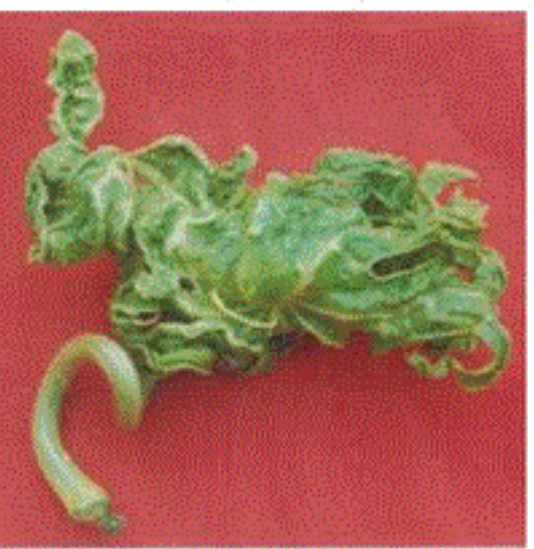

Leaf carling in downwards direction

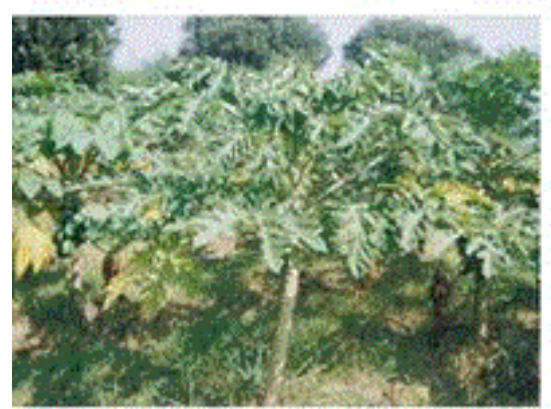

Leaf margins rolled upwards direction

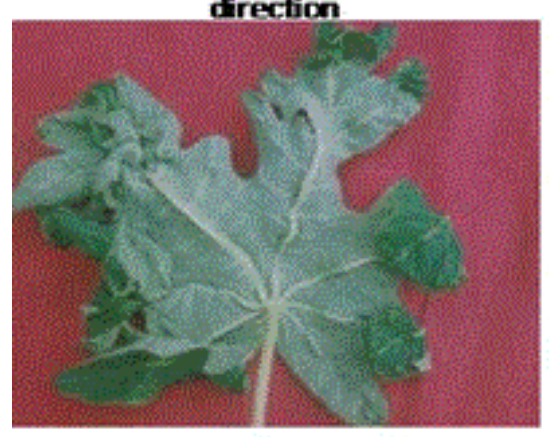

Twisting of vein

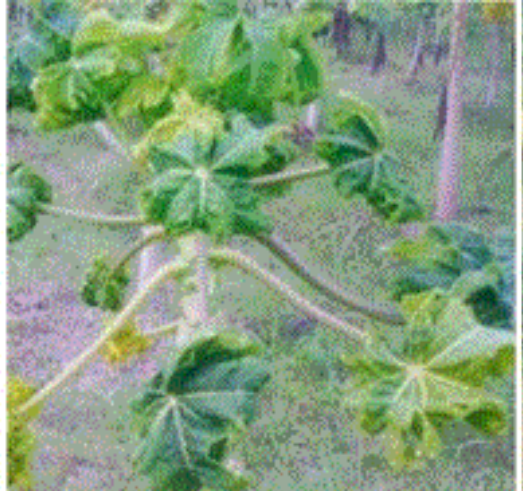

Rextuction of leaf size and vein dearing

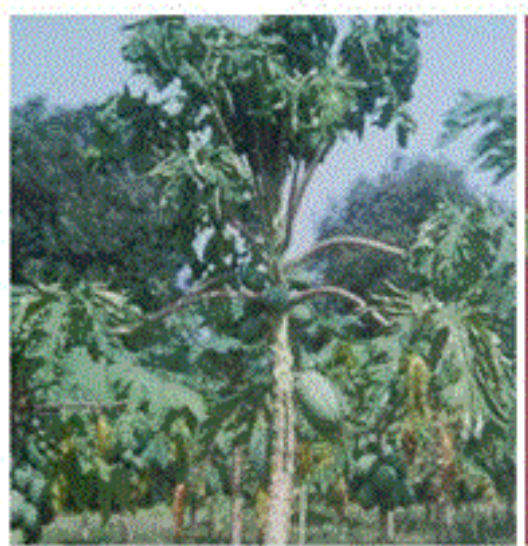

Leaf margins rolled inwards

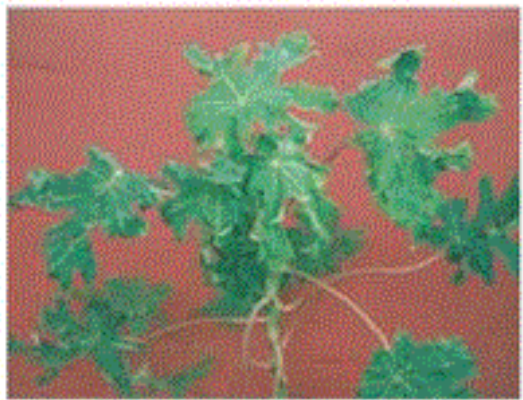

Infected plant turned dark green

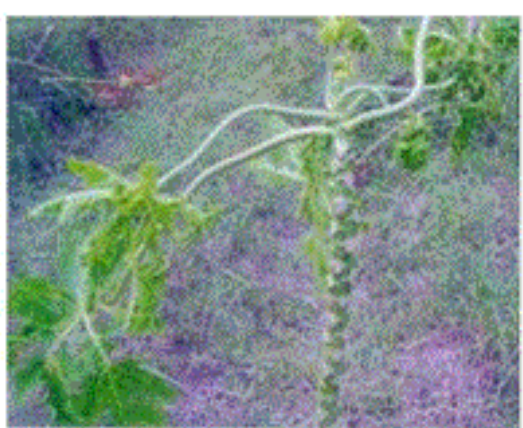

Petioles twisted in zigzag manner and bend trwards the main trurk

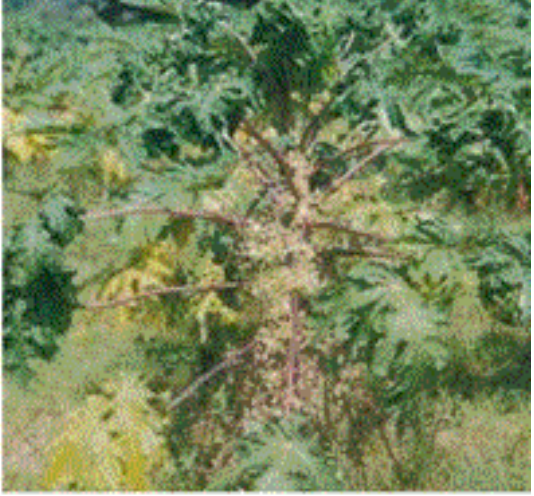

Leaf margins rolled downwards

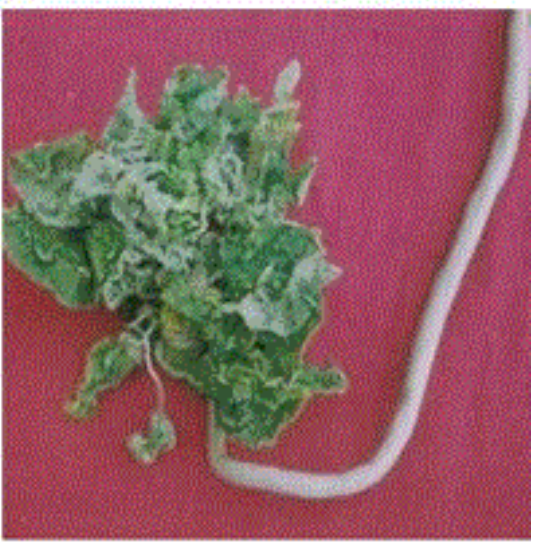

Leaf curling in upwards direction

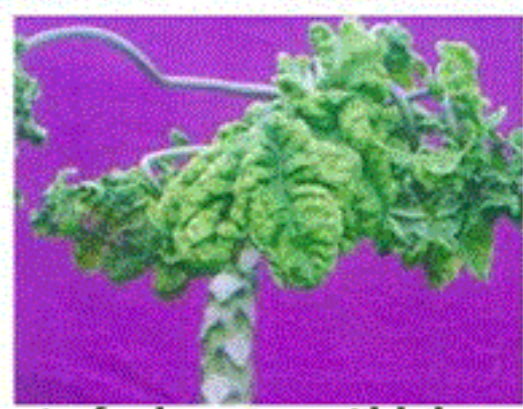

Leaf cur symptoms with lathery growth

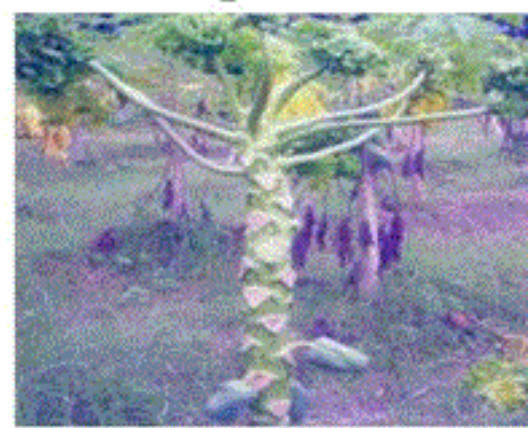

Leaf curl symptorns on plants with few small fruits

Figure 1. Symptoms caused by leaf curl virus on papaya plants. 
Table 3. Response of different papaya varieties against artificial inoculation of papaya leaf curl virus through white flies under glass house.

\begin{tabular}{|c|c|c|c|c|c|c|}
\hline \multirow{3}{*}{ Varieties } & \multicolumn{6}{|c|}{ Papaya leaf curl disease incidence (\%) } \\
\hline & \multicolumn{3}{|c|}{ 2006-07 } & \multicolumn{3}{|c|}{$2007-08$} \\
\hline & $20 \mathrm{DAI}$ & 40 DAI & $60 \mathrm{DAI}$ & $20 \mathrm{DAI}$ & 40 DAI & 60 DAI \\
\hline $\mathrm{CO}-1$ & 20.00 & 43.33 & 56.67 & 23.33 & 46.67 & 63.33 \\
\hline $\mathrm{CO}-2$ & 13.33 & 23.33 & 36.67 & 16.67 & 26.67 & 46.67 \\
\hline $\mathrm{CO}-3$ & 10.00 & 23.33 & 36.67 & 13.33 & 20.00 & 43.33 \\
\hline $\mathrm{CO}-4$ & 36.67 & 66.67 & 80.00 & 40.00 & 73.33 & 86.67 \\
\hline $\mathrm{CO}-5$ & 30.00 & 53.33 & 66.67 & 26.67 & 60.00 & 73.33 \\
\hline $\mathrm{CO}-6$ & 16.67 & 30.00 & 43.33 & 13.33 & 33.33 & 46.67 \\
\hline $\mathrm{CO}-7$ & 33.33 & 63.33 & 76.67 & 26.67 & 60.00 & 83.33 \\
\hline MF-1 & 40.00 & 66.67 & 80.00 & 43.33 & 60.00 & 83.33 \\
\hline Coorghoneydew & 16.67 & 30.00 & 43.33 & 20.00 & 36.67 & 50.00 \\
\hline Washington & 26.67 & 50.00 & 63.33 & 23.33 & 53.33 & 66.67 \\
\hline Pusa Delicious & 10.00 & 23.33 & 36.67 & 6.67 & 23.33 & 33.33 \\
\hline Pusa Nanha & 23.33 & 40.00 & 53.33 & 26.67 & 36.67 & 60.00 \\
\hline Pusa Dwarf & 16.67 & 30.00 & 43.33 & 20.00 & 36.67 & 50.00 \\
\hline Pusa Mejasty & 30.00 & 53.33 & 66.67 & 33.33 & 63.33 & 63.33 \\
\hline Pusa Gaint & 23.33 & 40.00 & 53.33 & 20.00 & 36.67 & 56.67 \\
\hline Harichaap & 6.67 & 13.33 & 23.33 & 10.00 & 16.67 & 20.00 \\
\hline SEm \pm & 1.05 & 1.75 & 2.40 & 1.25 & 1.98 & 2.87 \\
\hline C.D. at $5 \%$ & 2.86 & 4.76 & 6.53 & 3.40 & 5.39 & 7.81 \\
\hline
\end{tabular}

Table 4. Response of papaya varieties against papaya leaf curl diseases under field conditions during 2006-07and 2007-08.

\begin{tabular}{|c|c|c|c|}
\hline Category & Grade & Disease Incidence & V006-07 \\
\hline Immune & 1 & 0.00 & Nil \\
\hline Resistant & 2 & $0.1-25.0$ & Harichaap \\
\hline Moderately resistant & 3 & $25.1-50.0$ & $\begin{array}{c}\text { CO-2, CO-3, CO-6, Coorghoneydew, Pusa } \\
\text { Delicious and Pusa Dwarf }\end{array}$ \\
\hline Susceptible & 4 & $50.1-75.0$ & $\begin{array}{c}\text { CO-2, CO-3, CO-6, Coorghoneydew, Pusa } \\
\text { Delicious and Pusa Dwarf }\end{array}$ \\
\hline Highly susceptible & 5 & $75.1-100.00$ & Mejasty and Pusa Gaint \\
\hline
\end{tabular}

distortion of leaves, reduction of petioles, internodes and main shoot, vein enation and stunting of plants [5,12-14].

\section{Response of different papaya varieties against artificial inoculation of papaya leaf curl virus through white flies under glass house}

Data pertaining to leaf curl incidence on different cultivars (Table 3) exhibited maximum leaf curl incidence $(80.00$ and $86.67 \%)$ in cultivar Co-4 followed by MF-1 (80.00 and 83.33\%), Co-5 (66.67 and 73.33\%), Washington (63.33 and 66.67\%) at 60 days after inoculation during 2006-07 and 2007-08, respectively. While minimum leaf curl incidence of 23.33 and 20.00 per cent was observed on Harichaap cultivar during 2006-07 and 2007-08, respectively. Papaya varieties were categorized as immune to highly susceptible on the basis of disease incidence. Out of 16 varieties, none of the variety was found immune against leaf curl disease. Variety Harichaap was found resistant against leaf curl disease during both the years. While, six varieties viz., CO-2, CO-3, CO-6, Coorghoneydew, Pusa Delicious and Pusa Dwarf were rated as moderately resistant, six varieties viz., CO-1, CO-5, Washington, Pusa Nanha, Pusa Mejasty and Pusa Gaint as susceptible and three varieties viz., CO-4, CO-7 and MF-1as highly susceptible during both the years (Table 4).

\section{References}

1. Purcifull DE, Hiebert E (1978) Serological distinction of Watermelon mosaic virus isolates. Phytopathology 69: 112-116.

2. Cook MT (1931 a) New virus disease in Puerto Rico. Phytopath 21: 124.
3. Cook MT (1931 b) New virus disease in Puerto Rico. Jour Puerto Rico Dept Agric, 15: 193-195.

4. Thomas KM, Krishnaswami CS (1939) Leaf crinkle a transmissible disease of papaya Curr Sci8: 316.

5. Nariani TK (1956) Leaf curl of papaya. Indian Phytopath9: 151-157.

6. Pandey PK, Marathe TS (1986) A leaf crinkle disease of papaya in Maharashtra. Jour Maharashtra Agric Univ 11: 105-106.

7. Verma AK (1991) CIHNP, Lucknow, India, Annual Rept pp. 35-36.

8. Singh BP, Srivastava KM, Gupta RP, Abidi SMS (1978) Possible role of alternate hosts in natural spread of Papaya leaf curl virus to Carica papaya. Indian J Agron J Micro18: 188-189.

9. Verma AK (1994) CIHNP, Lucknow, India, Annual Rept pp 30-33.

10. ICAR (2004) Annual Report of the Central Institute of Sub-Tropical Horticulture, Lucknow.

11. Surekha SK, Mathur K, Shukla DD (1977) Virus diseases of papaya (Carica papaya) in Udaipur. Indian J Mycol Pl Pathol7: 115-121.

12. Verma AK (1996) Viral and Mycoplasmal Diseases of papaya (Carica papaya L) Fruits and Vegetables. Agnihotri VP, Om Prakash, Ram Kishun, Mishra AK (Eds.) International Books and Periodical Supply Service, New Delhi1: 156- 175.

13. Chang LS, Lea YS, Su HJ, Hung TH (2003) First report of Papaya leaf curl virus infecting papaya plants in Taiwan. Plant Disease 87: 204.

14. Singh A, Upadhyaya PP, Rao GP (2005) Distribution and serological Diagnosis of Papaya ringspot virus in Eastern Uttar Pradesh, India. J Mycol Pl Pathol35: 237-241.

Copyright: (C2017 Singh S. This is an open-access article distributed under the terms of the Creative Commons Attribution License, which permits unrestricted use, distribution, and reproduction in any medium, provided the original author and source are credited. 